and heterocyclic compounds are reviewed before the ground has been sufficiently prepared. Even without increasing the space allocated to the more elementary sections of the subject, the treatment could be made clearer for the beginner by the adoption of an improved system of paragraphs and headings, and by the more frequent use of illustrative diagrams.

The few drawings of apparatus here reproduced are evidently not the work of a chemist : they are badly proportioned (for example on pp. 4 and 18), and in one of them (p. 20) a Liebig condenser is shown with a jacket devoid of an inlet or outlet. The biological and pharmacological sides of the subject are excellently expounded, and it is this aspect of the book which is the most distinctive and attractive.

Plant Sociology: the Study of Plant Communities. Authorized English translation of "Pflanzensociologie". By Dr. J. Braun-Blanquet. Translated, revised and edited by Prof. George D. Fuller and Prof. Henry S. Conard. (McGrawHill Publications in the Agricultural and Botanical Sciences.) Pp. xviii +439 . (New York: McGraw-Hill Book Co., Inc.; London : McGraw-Hill Publishing Co., Ltd., 1932.) 27s. net. Plañ ecologists will welcome this English translation of a book which, for the last five years, has been perhaps the most stimulating and comprehensive exposition of the subject available. The volume is not a translation only, since the editors, who have had the full co-operation of the author throughout, have introduced certain subjects not appearing in the original and have included the results of research published since 1927 .

Perhaps the most interesting sections to English readers are those on the organisation of plant communities and the systematics of phytosociology. The former gives a clear account of Braun-Blanquet's methods of practical community-analysis, and the latter will open English eyes to the very rapid progress which has lately taken place in the floristic classification of plant communities.

The book has been admirably translated and is fully illustrated by plates and diagrams.

Philips' Vitamin Charts. 40 in. $\times 30$ in. Chart No. 1 : Vitamin Values of Foods. Chart No. 2: Diseases resulting from a Lack of Vitamins. (London : George Philip and Son, Ltd. ; Liverpool : Philip, Son and Nephew, Ltd., 1932.) Mounted on tanjib, with rollers, $8 s .6 d$. net each. These charts should prove of utility to those engaged in lecturing to students, or to other audiences not likely to be adversely affected by somewhat lurid colour illustrations of patients suffering from deficiency diseases. The colours applied on the first chart to common food stuffs and their packages also tend rather to the melodramatic, but in all cases the articles represented, like the deficiency diseases, are reasonably recognisable. In both charts a certain amount of accuracy has necessarily been sacrificed to the process of generalisation, for example, in ignoring the complexity of vitamin $\mathrm{B}$, failing to distinguish between carotene and vitamin $A$, using beriberi as the sole illustration of vitamin $\mathrm{B}$ deficiency, and overlooking the presence of vitamin $C$ in fresh meat. Nevertheless, provided the charts are used as convenient illustrative summaries by speakers and lecturers already conversant with the subject, these minor deficiencies, and the fact that they will tend to get further out of date in detail, need do no more than partly discount their undoubted value. A. L. B.

The Principles of Optics. By Prof. Arthur C. Hardy and Fred H. Perrin. (International Series in Physics.) Pp. xiii +632. (New York : McGrawHill Book Co., Inc.; London: McGraw-Hill Publishing Co., Ltd., 1932.) 36s. net.

THOSE who have learnt their optics as a branch of applied mathematics abounding in elegant problems devoid of any but an artistic value, will find (if they are young and mentally flexible) very refreshing reading in this remarkable volume. Readers of a more rigid habit of mind may find the occasional lack of a logical proof a little irritating.

Orer and above the conventional course of geometrical and physical optics to which we are all accustomed, we find very stimulating and suggestive discussions of such topics as photography, light sources, light-sensitive cells and physical photometry, colour, optical glass, the manufacture and testing of optical parts, the principles of design, telescopes, microscopes, photographic objectives, projection systems and stereoscopy.

The book is a noteworthy addition to an important series, and may be recommended alike to the academic and to the technical student.

\section{A. F.}

Steam Power Plant Engineering. By Louis Allen

Harding. Pp. viii +777. (New York: John Wiley and Sons, Inc. ; London: Chapman and Hall, Ltd., 1932.) 62s. 6d. net.

THIs book has been described as the "Compleat Power Engineer". The author of it has been president of an American technical society, professor of mechanical enginecring in an important college, a contributor to more than one important handbook, and the head of a firm. From the immense amount of data he has collected he has been able to compile a most comprehensive work which will prove of value to every power engincer who uses it. The thirteen chapters deal in turn with fucls, boilers, draught, firing appliances, boiler accessories, feed water apparatus, pumps, steam engines, turbines condensing plant, power plant cycles, valves, pipes and fittings, and lastly arrangements of steam power plants.

The book is designed to cover a complete course in steam generation and utilisation; it contains many references to recent papers on the subject and considerable data about the large American power stations. 